\author{
Baraniuk Kh. \\ Postgraduate \\ Department of Industrial Economics \\ Odessa National Academy of Food Technologies \\ Kanatna str., 112, Odessa, Ukraine, 65039 \\ E-mail: baranyuk.kristina@yandex.ua
}

\title{
ANALYSIS AND STRUCTURING OF EXTERNAL AND INTERNAL FACTORS OF INFLUENCE ON COMPETITIVENESS OF ENTERPRISE
}

The article describes the main factors that affect the competitiveness and efficiency of enterprises including small business enterprises in the food industry. The study of the stages of regular activities of the enterprise was made and the classification of external and interrnal factors that affect the efficiency and competitiveness of the enterprise in the context of the stages of its implementation was considered. industry.

Key words: Competitiveness, competitiveness factors of enterprises, small business enterprises, food

This work is licensed under a Creative Commons Attribution 4.0 International License http://creativecommons.org/licenses/by/4.0/

Statement of the problem and its connection with important scientific and practical tasks. Ensuring of the competitiveness of enterprises is one of the most important factors for the successful functioning of the enterprise in the domestic market of Ukraine and foreign markets. Previous studies have shown that relevant for the effective functioning of the industrial enterprises and ensuring the high level of competitiveness is, first and foremost, the opposition and the rapid response to changes in the external environment.

Providing of the high level of competitiveness of an industrial enterprise will help it to operate adequately in the market among other companies, to become the leader in the market and its separate segments, to provide its own enterprise with investments, to be able to participate in large-scale, and therefore profitable projects to implement its own products in a larger amount and in more profitable terms that will provide the enterprise with additional income and opportunity for development.

The development of small business is an important step to ensure the efficiency of the domestic economy and its further development, improve the living standards of the population, support of small and medium businesses in the country. To achieve this task, first of all you need a support of a small business by the state, improvement of the legislation that will strengthen the rights and enhance the activities of small businesses and enhance their own competitiveness, preferential taxation policy and in relation to such enterprises will provide the opportunities for their development, create additional jobs, replenishment of the state budget, and the like.

As it was shown by the previous research, to ensure the competitiveness of the small business enterprises it is necessary to conduct the research of influence of factors on competitiveness and efficiency of the activity.
The analysis of the latest publications on the problem. The study of the various aspects, the enhancing of the competitiveness of enterprises, including enterprises of the food industry and the impact of various factors on the level of competitiveness have been made by many domestic and foreign scientists. Among them, the significant contribution to the study of competition and competitiveness over the various aspects was made by the following scientists-economists: O. B. Alekhin, L. I. Andreeva, Y. M. Afanasyeva, J. Bauer, E. Brulev, V. V. Burlakov, K. O. Vaskovska, E.S. Vishnevetska, V.F. Gagarinova, A. Dayana, H. V. Zadorozhna, J. Zusman, A. Costin, N. M. Kuprina, J. Lodge, V. Malitskaya, A. Ollivier, M. Porter, N.O. Pustova, O. Rossihina, S. I. Savchuk, D.B. Stanko, L. Tyson, A. Thompson, R. Urse, T.B. Kharchenko etc.

Improving of the competitiveness of enterprises of food industry in Ukraine and Odessa region which this industry is particularly important for and identifying the factors that have the significant influence on the level of competitiveness of the enterprise, their systematization and classification are particularly relevant nowadays when many industrial enterprises are unprofitable and have some problems with implementation of their own products in the domestic market as well as in export. Therefore, there is a need for detailed study of this problem, finding ways to improve the competitiveness of the food industry enterprises, including small businesses, and also the study of their condition, methods, and tools of competitiveness, systematization and classification of the main factors of influence, methods of estimation the level of competitiveness of the processes of such provision and improvement the efficiency of activity [1, p. 34; 2, p. 107].

Forming of the aims of the research. The purpose of this article is the study of competitiveness factors 
and their systematization concerning impact on regular activities of food industry enterprises, including small businesses, providing of their competitiveness and future development and management of the competitiveness.

Giving an account of the main results and their substantiation. The enterprise's competitiveness characterizes the ability of an enterprise to represent their products in the domestic and foreign markets among the other representatives of similar goods and under the certain conditions. It can be noted that the competitiveness of any enterprise is, primarily, the result of its advantages over other companies that serve as its competitors; therefore, to improve the level of their own competitiveness, the enterprise has to solve several strategic tasks that will lead to improvement the efficiency of all its activities [1, p. 34].

As it was shown by previous studies [1, p. 34] the category of "competitiveness" is interpreted by scientists in different ways and is the broad term that has no universal approach in determining the essence as well as the types. The studies have shown that there is no unified, systematic approach to the classification of factors of but most authors prefer external and internal factors, as factors that have the most significant influence on the level of competitiveness at the enterprise $[4,5]$.

We agree with K. O. Vaskovska [6] who suggests that we summarize the classifications and group them into the endogenous - domestic factors and exogenous factors - external factors, structuring them into the objective ones that do not depend on the activity of enterprise, conditionally objective which may, depending on individual circumstances, depend or not depend on the activity of enterprise and subjective which depend on the activity of enterprise, as well as detailing the general and specific factors. So, to external factors K. O.Vaskovska refers: international, political-legal, economical, natureenvironmental factors and factors of influence of globalization processes, to the internal common factors she refers: the resource potential, socio-psychological factors, technical-technological factors, organizationaleconomical factors, the parameters of production, marketing and sales factors, the image of the enterprise and the efficiency of regular activities [6].

At the same time, we can't disagree with O.B. Alekhin [7] who distinguished two groups of factors: depending on factor influence and factors, under the influence of which, the enterprise can improve their status in relation to the condition of the same factors at the enterprises-competitors, that is, to maintain, improve or create the competitive advantages. The scientist notes that to increase the level of competitiveness of the enterprise is possible by means of the system of factors of the first group, and using the factors of the second group to determine the direction of planning the activity of enterprise [7].

In our view, to the external factors, in addition to those that were suggested by K. O. Vaskovska, it is necessary to add factors such as: regulations, regarding support of the domestic producers, including small businesses and promotion of domestic products, support of the competitiveness as well. In our opinion, the competitiveness of any enterprise depends on the effectiveness of its activity, namely, on all types of its regular activities. Operating (main) activity allows to obtain the certain level of profit from the implementation of enterprise's products. With the significant level of the profit obtained from operating activities, the enterprise should invest surplus funds in production - operating activity to ensure and improve the competitiveness, and in the capital of other enterprises - the financial (investment) activities that will allow to increase the sales of products, modernize the production, expand the range, improve the quality of product, reduce its costs, increase the ways to promote products at the market, ensure its competitiveness [3, p. 133 - 134]. The studies have shown that small businesses are primarily characterized by operational (main) and other regular activities.

There are many different factors that affect the efficiency of the enterprise's activity. At the deeper study of this issue wide variety of interpretations and approaches to definition, classification and level of influence of competitiveness were revealed, renewal of the fixed assets and introduction of new technologies through preferential - taxation and credit policies. Especially these factors have an important influence exactly in the modern period of operation of enterprises and promote the development of small businesses as the most vulnerable sector of activity in the economy of our country.

We agree with A. V. Savitsky [8. p. 166-167] who considers that the qualitative characteristics of products are formed at all stages of its life cycle, but studying the competitive potential of the enterprise in the system of impact the factors of competitiveness only to improve the quality of product, A.V. Savitskiy systematized arrangement of the stages in the order of their impact on the quality of the products that changed the logical sequence of the stages in the system of the regular activities of the enterprise, but, in our opinion, studying the influence of internal and external factors of competitiveness at all stages of the enterprise activity that need to be structured depending on the phases of regular activity. We have added and improved the structuring of internal and external factors in the context of phases of regular activities that is presented in the table 1 .

We agree with K. O. Vaskovska [6] about the fact that during the conducting of the internal analysis of the competitiveness at the enterprise, it is necessary to divide partial, internal factors into individual depending on activities and needs of each enterprise, and if it is necessary in the future to spend even more on their detailing.

Studying the publications of scientists concerning the problem of definition and classification the factors of competitiveness it was revealed that most of the authors distinguish factors according to the certain criteria (table 2). Each of the authors believes that to maintain and increase the competitive potential of the enterprise it is necessary to ensure the level of competitiveness according to the specified factor signs. 
Table 1

Structuring of the internal and external factors of competitiveness in the context of stages of implementation of regular activities of the enterprise*

\begin{tabular}{|c|c|c|}
\hline $\begin{array}{l}\text { Stages of the regular } \\
\text { activities of } \\
\text { the enterprise }\end{array}$ & Internal factors & External factors \\
\hline Organizational stage & $\begin{array}{l}\text { Legal and organizational structure; production } \\
\text { structure; professional and qualification level } \\
\text { of the workforce; the existence of the system } \\
\text { of production management and product quali- } \\
\text { ty; automation of management; educational } \\
\text { potential of the enterprise; the use of the latest } \\
\text { computer programs in the development of the } \\
\text { product and its packaging; availability of the } \\
\text { conditions to increase quality at the enterprise; } \\
\text { information provision with operative informa- } \\
\text { tion. }\end{array}$ & $\begin{array}{l}\text { The activities of state bodies, economical, } \\
\text { fiscal and monetary policy of the state; de- } \\
\text { velopment of the support industries of econ- } \\
\text { omy; location, natural-climatic and envi- } \\
\text { ronmental conditions; deepening of integra- } \\
\text { tion processes; state tax policy; regulatory } \\
\text { and legal support of the state, etc. }\end{array}$ \\
\hline Technological stage & $\begin{array}{l}\text { Technological equipment of the enterprise; } \\
\text { resource and material base; the quality of raw } \\
\text { materials and the ability of its processing, the } \\
\text { application of the new technologies of produc- } \\
\text { tion and packaging, etc. }\end{array}$ & $\begin{array}{l}\text { The conjucture of raw materials markets, } \\
\text { labor and means of production, markets and } \\
\text { financial resources; the import of raw mate- } \\
\text { rials; governmental regulation of the use of } \\
\text { the latest technologies, terms of providing } \\
\text { with short-term loans. }\end{array}$ \\
\hline Marketing stage & $\begin{array}{l}\text { Market saturation with goods of the enter- } \\
\text { prise; competitive advantages of the enter- } \\
\text { prise, availability of opportunities of the en- } \\
\text { terprise to increase its market share; pricing of } \\
\text { products; analysis of the market and its seg- } \\
\text { ments; analysis of competitor's activity; cus- } \\
\text { tomer surveys; advertising and promotional } \\
\text { campaign, etc. }\end{array}$ & $\begin{array}{l}\text { The supply and demand for goods produced } \\
\text { by the enterprises; changes in the domestic } \\
\text { market of the country; development of new } \\
\text { markets; purchasing ability and consumer } \\
\text { preferences of the population (social); the } \\
\text { intensity of competition on the target market } \\
\text { (competitive environment); the level of } \\
\text { competitiveness of the industry; the use of } \\
\text { outsourcing (contracting) etc. }\end{array}$ \\
\hline Production stage & $\begin{array}{l}\text { Stage of production; rework and prevention of } \\
\text { unproductive losses; efficiency of resource } \\
\text { management of the enterprise; the state of } \\
\text { fixed assets and utilization of production ca- } \\
\text { pacity; cost management of the enterprise, etc. }\end{array}$ & $\begin{array}{l}\text { International cooperation between corpora- } \\
\text { tions, enterprises on the production of } \\
\text { goods; the use of outsourcing (contracting) } \\
\text { in the regular activities of the enterprise, etc. }\end{array}$ \\
\hline Sales stage & $\begin{array}{l}\text { The volume of sales; distribution costs; im- } \\
\text { provement of distribution; improvement of } \\
\text { their own sales networks and cooperation with } \\
\text { other trading networks; the increase in the cost } \\
\text { of current assets of the enterprise; participa- } \\
\text { tion in exhibitions, fairs, advertising and pro- } \\
\text { motional campaigns; profitability and produc- } \\
\text { tivity of products and enterprise's capital, etc. }\end{array}$ & $\begin{array}{l}\text { The economic condition of the country; the } \\
\text { pricing policy of the country and the com- } \\
\text { petitors; the export-import policy of the } \\
\text { country; the tax policy of the country; the } \\
\text { policy of trade networks; competitive advan- } \\
\text { tages of the competing enterprises; the state } \\
\text { and the market saturation of goods; purchas- } \\
\text { ing ability and consumer preferences of the } \\
\text { population; seasonal fluctuations in sales of } \\
\text { goods etc. }\end{array}$ \\
\hline Innovation stage & $\begin{array}{l}\text { Upgrades of equipment and use of new tech- } \\
\text { nologies, introduction of new equipment and } \\
\text { means of labor; the introduction of innova- } \\
\text { tions in manufacture of the product and its } \\
\text { packaging; introduction of the newest } \\
\text { processes of automation production and com- } \\
\text { puter graphics; development the systems of } \\
\text { deep processing of raw materials; improve- } \\
\text { ment of trade networks etc. }\end{array}$ & $\begin{array}{l}\text { Development of new technologies and scien- } \\
\text { tific and technical progress; development of } \\
\text { innovation; increase of research and devel- } \\
\text { opment operations; development of re- } \\
\text { source-saving technologies; development of } \\
\text { new sources of energy; improving the sys- } \\
\text { tem of standardization and certification of } \\
\text { products; state policy to support innovation } \\
\text { activity of enterprises etc. }\end{array}$ \\
\hline
\end{tabular}


Continue of table 1

\begin{tabular}{|c|c|c|}
\hline $\begin{array}{c}\text { Stages of the regular } \\
\text { activities of } \\
\text { the enterprise }\end{array}$ & Internal factors & External factors \\
\hline $\begin{array}{l}\text { Financial-investment } \\
\text { stage }\end{array}$ & $\begin{array}{l}\text { Attracting of investments; financial-credit and } \\
\text { investment policy and activity of enterprise; } \\
\text { quality of products; the state of competitiveness } \\
\text { and efficiency of enterprise's activity; the state of } \\
\text { liquidity of assets and creditworthiness of the } \\
\text { enterprise; profitability and productivity of prod- } \\
\text { ucts and enterprise's capital; use of outsourcing } \\
\text { (contracting); and etc. }\end{array}$ & $\begin{array}{l}\text { Financial and investment policy of the } \\
\text { state; tax policy of the state; the state of } \\
\text { the economy; investment climate in the } \\
\text { state; the state support of small business } \\
\text { development in the country; the use of } \\
\text { outsourcing (contracting) etc. }\end{array}$ \\
\hline
\end{tabular}

* Updated and improved by the author based on sources [8, p. 166-167; 9, p. 279-280; 10, p. 297; 11, p. 89-90; 12 , p. 65-66]

So, one of the interesting studies of the level of competitiveness of the enterprise is its study on the basis of the competitive level that have been shown in the works of E. Smolyanova and V. Malitska [13] who identified three levels of competitiveness.

Classification of factors of competitiveness on the grounds of their distribution*

\begin{tabular}{|c|c|c|c|c|c|c|c|c|c|c|c|c|c|c|c|c|c|c|c|c|}
\hline $\begin{array}{l}\text { Features of distribution and classifica- } \\
\text { tion of factors }\end{array}$ & $\begin{array}{c}\dot{\bar{\Xi}} \\
\overrightarrow{\tilde{E}} \\
\dot{\sim} \\
\dot{\sim}\end{array}$ & 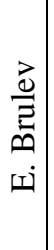 & $\begin{array}{l}\frac{\pi}{y} \\
\tilde{J} \\
0 \\
\frac{y}{v} \\
\tilde{J} \\
> \\
\dot{0} \\
\dot{v} \\
\dot{v}\end{array}$ & 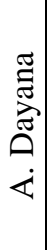 & 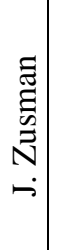 & 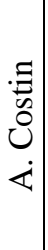 & 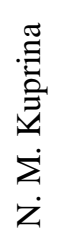 & 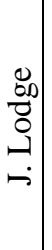 & 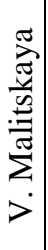 & 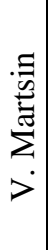 & 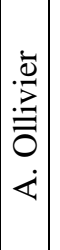 & $\begin{array}{l}\dot{\bar{s}} \\
\stackrel{0}{0} \\
\stackrel{2}{\dot{2}} \\
\dot{\Sigma}\end{array}$ & 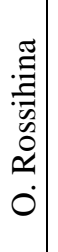 & 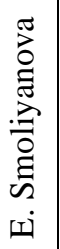 & 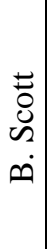 & 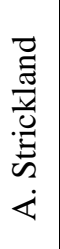 & 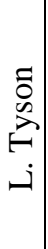 & 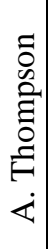 & $\begin{array}{l}\dot{8} \\
\dot{m} \\
\dot{\omega} \\
\dot{\sim} \\
\end{array}$ & $\begin{array}{l}\frac{\partial}{0} \\
\frac{0}{3} \\
\dot{1} \\
0\end{array}$ \\
\hline $\begin{array}{l}\text { 1. The object of the research: } \\
\text { a) Key factors are divided into the fol- } \\
\text { lowing: } \\
\text { - depend on technology; } \\
\text { - belong to the sphere of production; } \\
\text { - relate to the sale of products; } \\
\text { - enter the field of marketing; } \\
\text { - belong to the professional skills; } \\
\text { - associated with the organizational } \\
\text { capabilities; }\end{array}$ & & & & & & & & & & & & & & & & + & & + & & \\
\hline $\begin{array}{l}\text { - other key tactors of success } \\
\text { b) Concept of goods and services, their } \\
\text { quality and price, means of trading, } \\
\text { resale training; foreign trade; finances } \\
\text { of the enterprise }\end{array}$ & & & & + & & & & & & & + & & & & & & & & + & \\
\hline $\begin{array}{l}\text { 2. Nature of occurrence: } \\
\text { - basic and advanced; } \\
\text { - general and specialized; } \\
\text { - natural and artificial } \\
\end{array}$ & + & & & & + & & & + & & & & + & & & + & & + & & & \\
\hline $\begin{array}{l}\text { 3. Scope: } \\
\text { - external and internal }\end{array}$ & & + & + & & & & & & & + & & & & & & & & & & \\
\hline $\begin{array}{l}\text { 4. Handling: } \\
\text { - controlled and uncontrolled; } \\
\text { - managed and unmanaged }\end{array}$ & & & & & & + & & & & & & & + & & & & & & & \\
\hline $\begin{array}{l}\text { 5. Level of specialization: } \\
\text { - integral and specific }\end{array}$ & & & & & & & & & & & & & & & & & & & & + \\
\hline \multirow{2}{*}{$\begin{array}{l}\text { 6. Competitive level: } \\
\text { a)factors: mega, macro, microlevel; } \\
\text { b)factors: macro, meso, micro, mini, } \\
\text { nano level }\end{array}$} & & & & & & & & & + & & & & & + & & & & & & \\
\hline & & & & & & & + & & & & & & & & & & & & & \\
\hline
\end{tabular}

* Compiled by the author based on the analysis of the sources [14] 
But taking into account the approach of improving the level of competitiveness on the same grounds that was developed by N. M. Kuprina who structured the four levels of competitiveness, it is possible to complete and improve the classification mentioned above on the basis of the competitive level and to expand it to the five levels of assessment of the competitiveness (table 3). It should be noted that in the activities of small business enterprises the first level (megalevel) is usually absent.

Table 3

Classification of the factors influencing the formation and development of competitiveness of the enterprise depending on the level of the object research and the level of competitiveness*

\begin{tabular}{|c|c|c|}
\hline $\begin{array}{l}\text { The level of research the } \\
\text { object's competitiveness }\end{array}$ & Level of competitiveness & $\begin{array}{l}\text { Factors influencing the formation and development of } \\
\text { competitiveness of the enterprise }\end{array}$ \\
\hline Metalevel & $\begin{array}{l}\text { Competitiveness } \\
\text { of the international } \\
\text { corporations } \\
\text { (factors uncontrolled } \\
\text { by the state) }\end{array}$ & $\begin{array}{l}\text { Globalization; international specialization and division } \\
\text { of labor; information revolution and scientific and } \\
\text { technological progress; improvement production tech- } \\
\text { nology; geographic position; climatic conditions etc. }\end{array}$ \\
\hline Macrolevel & $\begin{array}{l}\text { Competitiveness of the } \\
\text { country } \\
\text { (factors controlled by the } \\
\text { government, uncontrolled } \\
\text { by the company) }\end{array}$ & $\begin{array}{l}\text { Imperfection of the state mechanism; tax policy; state } \\
\text { of economy of the country; investment climate in the } \\
\text { country; necessity to create the effective institutional } \\
\text { environment; level of education and skills of the popu- } \\
\text { lation; the level of development of general infrastruc- } \\
\text { ture; level of technological development; demographic } \\
\text { situation; presence and degree of influence of natural } \\
\text { monopolies on economic development, features of } \\
\text { geopolitical location; geographic position; climatic } \\
\text { conditions etc. }\end{array}$ \\
\hline Mesolevel & $\begin{array}{l}\text { Competitiveness } \\
\text { of the region, province, } \\
\text { particular industry } \\
\text { (the factors which are under } \\
\text { the control of the state and } \\
\text { local authorities) }\end{array}$ & $\begin{array}{l}\text { Policy of the local authorities; level of education and } \\
\text { skills of the population; the level of development of } \\
\text { general infrastructure; historically formed consumer } \\
\text { aspects; features of raw materials base in the region } \\
\text { and its availability; productivity of the region; geo- } \\
\text { graphical location; climatic conditions. }\end{array}$ \\
\hline Microlevel & $\begin{array}{l}\text { Competitiveness } \\
\text { of the enterprise, products } \\
\text { (factors controlled } \\
\text { by the enterprise) }\end{array}$ & $\begin{array}{l}\text { Organizational legal and production structure; profes- } \\
\text { sional and qualification level of the workforce; the ef- } \\
\text { fectiveness of human resource management; quality of } \\
\text { products; distribution of products of the major manu- } \\
\text { facturers in retail outlets; production technology; stable } \\
\text { performance; the degree of brand awareness; level of } \\
\text { prices; design of packaging; number of items; the level } \\
\text { and flexibility of service, speed and timeliness of order } \\
\text { fulfillment; customer orientation; financial policy; per- } \\
\text { sonnel management; productivity, etc. }\end{array}$ \\
\hline Nanolevel & $\begin{array}{l}\text { Competitiveness } \\
\text { of the certain private } \\
\text { entrepreneur } \\
\text { (factors controlled by the } \\
\text { private entrepreneur- } \\
\text { physical entity) }\end{array}$ & $\begin{array}{l}\text { Organizational legal and production structure; profes- } \\
\text { sional and qualification level of the private entrepre- } \\
\text { neur, operating personnel; production technology; } \\
\text { product quality; the degree of brand awareness; level of } \\
\text { prices; design of packaging; number of items; the level } \\
\text { and flexibility of service, speed and timeliness of order } \\
\text { fulfillment; customer orientation; financial policy; } \\
\text { profit level of the private entrepreneur etc. }\end{array}$ \\
\hline
\end{tabular}

* Compiled and improved by the author based on the sources $[13 ; 14 ; 15]$

Conclusions and prospects of the further investigations. For the proper functioning of any domestic industrial enterprise it is necessary to provide primarily the high level of competitiveness among other enterprises and the state support especially for small business enterprises. The study showed that the competitive potential of 
the food industry enterprises, including small businesses is primarily affected by the number of factors in each particular moment of their activities. We have made the research and improved the classification of the factors influencing the enterprise's competitiveness through the structuring of internal and external factors of the competi- tiveness in the context of the stages of implementation of regular activities and depending on the level of the object research and the level of competitiveness. The study showed that there are many definitions, approaches and classifications to determine the level of competitiveness that requires the additional research.

\section{References}

1. Baraniuk , K. O. (2016). Konkurentospromozhnist: sutnist ta ob'iekty doslidzhennia . Ekonomika kharchovoi promyslovosti, 8(4), 33-39.

2. Pavlov, O. I. (2015). Sotsio-ekoloho-ekonomichnyi rozvytok ahroprodovolchoi sfery Ukrainy v suchasnykh umovakh: problemy ta shliakhy yikh rozviazannia . Odesa: Astroprynt.

3. Valuiev, B. I. (2001). Teoriia bukhhalterskoho obliku. Odesa: Prynt Maister.

4. Khvychyia, L. (1998). Obespechenye konkurentosposobnosty fyrmы. Byznes Ynform, 5, 79.

5. Pustova, N. O. (2006). Orhanizatsiino-ekonomichnyi mekhanizm zabezpechennia konkurentospromozhnosti pidpryiemstv (za materialamy kharchovykh pidpryiemstv Khersonskoho rehionu). K.

6. Vaskovska, K. O. (2015). Rozvytok upravlinnia konkurentospromozhnistiu pidpryiemstv kharchovoi promyslovosti. Odesa.

7. Alokhin, O. B. (2011). Prymenenye metodov systemnoho analyza v zadachakh planyrovanyia deiatelnosty po povыshenyiu konkurentosposobnosty predpryiatyi . Ekonomika: realii chasu, 1, 180-186.

8. Savitskyi , A. V. (2013). Formuvannia konkurentnoho potentsialu pidpryiemstva v systemi vplyvu zovnishnikh ta vnutrishnikh faktoriv pidvyshchennia yakosti produktsii. Visnyk Khmelnytskoho natsionalnoho universytetu, 5(1), 166-168.

9. Huzar , B. S. (2012). Osnovni faktory vplyvu na konkurentospromozhnist produktsii. Innovatsiina ekonomika, 11(37), 277-280.

10. Zaitseva , L. O. (2012). Klasyfikatsiia faktoriv konkurentospromozhnosti pidpryiemstva . Visnyk skhidnoukrainskoho natsionalnoho universytetu imeni Volodymyra Dalia, 8(179), 293-300.

11. Maliuha, L. M. (2012). Upravlinnia faktoramy konkurentospromozhnosti pidpryiemstv . Innovatsiina ekonomika, 11(37), 88-91.

12. Smoleniuk , P. S. (2012). Pidvyshchennia yakosti produktsii - osnovna umova zabezpechennia yii konkurentospromozhnosti . Innovatsiina ekonomika, 5(31), 64-68.

13. Kuzmynych, H. H. (2011). Faktord, vlyiaiushchye na konkurentosposobnost predprynymatelskykh struktur. Retrieved February, 2017, from http://comnaua.isea.ru/files/s1/37\%20\%D0\%9A\%D1\%83\%D0\%B7\%D1\%8C\%D0\%BC\%D0\%B8\%D0\%BD\%D0\%B8\%D1\%87. pdf

14. Zaitseva , L. O. (2012). Klasyfikatsiia faktoriv konkurentospromozhnosti pidpryiemstva. Retrieved February, 2107, from http://dspace.luguniv.edu.ua/xmlui/bitstream/handle/123456789/525/zaitseva\%201\%2012\%20052012.pdf?sequence=1 \&isAllowed=y

15. Kupryna, N. M. (2011). Konkurentosposobnost predpryiatyia: vydы y uroven . Formuvannia rynkovoi ekonomiky: zb. nauk. prats. - Spets. Vyp. Rehionalnyi rozvytok Ukrainy: problemy ta perspektyvy, 576-570.

\section{Баранюк К.А.} аспирант

кафедра экономики промышленности

Одесская национальная академия пищевых технологий

ул. Канатная, 112, г. Одесса, Украина, 65039

E-mail: baranyuk.kristina@yandex.ua

\section{АНАЛИЗ И СТРУКТУРИРОВАНИЕ ВНЕШНИХ И ВНУТРЕННИХ ФАКТОРОВ ВЛИЯНИЯ НА КОНКУРЕНТОСПОСОБНОСТЬ ПРЕДПРИЯТИЯ}

Целью данной статьи является исследование факторов конкурентоспособности, их систематизация по влиянию на обычную деятельность предприятий пищевой промышленности, в т.ч. предприятия малого бизнеса, с целью обеспечения их конкурентоспособности и дальнейшего развития и управлением конкурентоспособностью. 
Исследование показало, что конкурентный потенциал пищевой промышленности, в т.ч. малого бизнеса, в первую очередь зависит от влияния ряда фракторов в каждый конкретный момент их деятельности. Нами было проведено исследование и усовершенствована классификация фракторов, влияющих на конкурентоспособность предприятия за счет структурирования внутренних и внешних факторов конкурентоспособности в разрезе этапов осуществления обычной деятельности и в зависимости от уровня исследования объекта и уровня конкурентоспособности. Проведенное исследование показало, что существует множество определений, подходов и классификаций определения уровня конкурентоспособности предприятия, что требует дополнительных исследований.

Ключевые слова: Конкурентоспособность, факторы конкурентоспособности предприятия, предприятие малого бизнеса, пищевая промышленность.

\section{Баранюк X.O.}

аспірант

кафедра економіки промисловості

Одеська національна академія харчових технологій

вул. Канатна, 112, м. Одеса, Україна, 65039

E-mail: baranyuk.kristina@yandex.ua

\section{АНАЛІЗ ТА СТРУКТУРУВАННЯ ЗОВНІШНІХ ТА ВНУТРІШНІХ ФАКТОРІВ ВПЛИВУ НА КОНКУРЕНТОСПРОМОЖНІСТЬ ПІДПРИЕМСТВА}

В статті розглянуто основні фрактори, які впливають на конкурентоспроможність та ефективність діяльності підприємства, в т.ч. підприємств малого бізнесу в харчової промисловості. Проведено дослідження етапів здійснення звичайної діяльності підприємства та розглянута класифікація внутрішніх та зовнішніх фракторів, що впливають на ефективність діяльності та конкурентоспроможності підприємства у розрізі етапів її здійснення.

Дослідження показало, що конкурентний потенціал підприємств харчової промисловості, в т.ч. малого бізнесу, в першу чергу залежить від впливу ряду фракторів у кожний конкретний момент їх діяльності. Нами було проведено дослідження та удосконалена класифікація фракторів, які впливають на конкурентоспроможність підприємства за рахунок структурування внутрішніх та зовнішніх факторів конкурентоспроможності у розрізі етапів здійснення звичайної діяльності та в залежності від рівня дослідження об'єкта та рівня конкурентоспроможності. Проведене дослідження показало, що існує безліч визначень, підходів та класифікацій визначення рівня конкурентоспроможності підприємства, що потребує додаткових досліджень.

Ключові слова: Конкурентоспроможність, фрактори конкурентоспроможності підприємства, підприємство малого бізнесу, харчова промисловість.

\section{Література}

1. Баранюк Х.О. Конкурентоспроможність: сутність та об'єкти дослідження / Х.О. Баранюк // Економіка харчової промисловості. - 2016. - Т. 8, Вип. 4. - С. 33 - 39.

2. Соціо-еколого-економічний розвиток агропродовольчої сфери України в сучасних умовах: проблеми та шляхи їх розвязання : [монографія] / [ О.І. Павлов, К.Б. Козак, Д.Ф. Крисанов та ін.] ; за заг. ред. О.І. Павлова. Одеса: Астропринт, 2015. - 512c.

3. Теорія бухгалтерського обліку: [навч. посіб.] / за ред. проф. Б.І. Валуєва. - Одеса: ОДЕУ: Принт Майстер, 2001. $-256 \mathrm{c}$.

4. Лиана Хвичия. Обеспечение конкурентоспособности фирмы / Л. Хвичия // БизнесИнформ. - 1998. - № 5. - C. 79.

5. Пустова Н.О. Організаційно-економічний механізм забезпечення конкурентоспроможності підприємств (за матеріалами харчових підприємств Херсонського регіону) : автореф. дис. на здобуття наук. ступеня канд. ек. наук : спец. 08.06.01 «Економіка, організація і управління підприємствами» / Пустова Н.О. - К., 2006. - 25 с.

6. Васьковська К.О.: Розвиток управління конкурентоспроможністю підприємств харчової промисловості: автореф. дис. на здобуття наук. ступеня канд. ек. наук: спец. 08.00 .04 «Економіка та управління підприємствами (за видами економічної діяльності)» / Васьковська К.О. - Одеса, 2015. - 20 с.

7. Альохін О.Б. Применение методов системного анализа в задачах планирования деятельности по повышению конкурентоспособности предприятий / Альохін О.Б., Ванина Н.Н. // Економіка: реалії часу. - 2011. - № 1. - C. $180-186$. 
8. Савіцький А. В. Формування конкурентного потенціалу підприємства в системі впливу зовнішніх та внутрішніх факторів підвищення якості продукції / А. В. Савіцький. // Вісник Хмельницького національного університету. - 2013. - №5, Т. 1. - С. 166 - 168.

9. Гузар Б.С. Основні фактори впливу на конкурентоспроможність продукції / О.С. Цикалюк, Б.С. Гузар // Інноваційна економіка. - 2012. - №11(37). - С.277 - 280.

10. Зайцева Л.О. Класифікація факторів конкурентоспроможності підприємства // Л.О. Зайцева / Вісник східноукраїнського національного університету імені Володимира Даля. - 2012. - № 8 (179). - С.293 - 300.

11. Малюга Л.М. Управління факторами конкурентоспроможності підприємств / Л.М. Малюга // Інноваційна економіка. - 2012. - № 11 (37). - С. 88 - 91 .

12. Смоленюк П.С. Підвищення якості продукції - основна умова забезпечення iї конкурентоспроможності / П.С. Смоленюк // Інноваційна економіка. - 2012. - № 5 (31). - С. 64 - 68.

13. Кузьминич Г.Г. Факторы, влияющие на конкурентоспособность предпринимательских струк-

тур [Електронный ресурс] / Г.Г. Кузьминич// Известия Иркутской государственной экономической академии. 2011. - № 4/ - Режим доступу: http://comnauka.isea.ru/files/s1/37\%20\%D0\%9A\%D1\%83\%D0\%B7\%D1\%8C\%D0\%BC\%D0\%B8\%D0\%BD\%D0\%B8\%D1\%87 .pdf

14. Зайцева Л.О. Класифікація факторів конкурентоспроможності підприємства [Електронний ресурс] / Л.О. Зайцева // Вісник Східноукраїнського національного університету ім. В. Даля. - 2012. - № 8 (179). - С. 293-300. - Режим доступу: http://dspace.luguniv.edu.ua/xmlui/bitstream/handle/123456789/525/zaitseva\%201\%2012\%20052012.pdf?sequence=1 \&isAllowed $=\mathrm{y}$

15. Куприна Н.М. Конкурентоспособность предприятия: виды и уровень / Н.М. Куприна // Формування ринкової економіки: зб. наук. праць. - Спец. Вип. Регіональний розвиток України: проблеми та перспективи: у 2-х ч. - Ч.1. - К.: КНЕУ, 2011 - С. 567 - 570. 